\title{
ANALYSIS OF THE RELATIONSHIP BETWEEN CHARACTERISTICS OF USERS OF ELECTRONIC MONEY APPLICATIONS TO INTENTIONS AND USAGE BEHAVIOR
}

\author{
Jeddawi Muhammd Fachril Husain*, Yuliati Lilik Noor, Nurrochmat Dodik Ridho \\ School of Business, Bogor Agricultural University, Bogor, Indonesia \\ *E-mail: fachriljeddawi@gmail.com
}

\begin{abstract}
Data from the Indonesian Financial Technology Association (IFA) and OJK in 2016 showed that the largest percentage in financial technology was payment sector. However, the Central Jakarta survey data in 2017 shows that the cash payment method is still the consumer's main choice of $77 \%$ in making payments. The answers to the research are arranged using a Likert scale to be processed with Crosstab Analysis. The results showed that transportation services had the largest percentage in online transactions of $37.33 \%$.. The results of the study also showed that $56.84 \%$ of users used electronic money applications for less than ten times in one month. The reason for using the most electronic money is practically $47.02 \%$.
\end{abstract}

\section{KEY WORDS}

Behavioral intention, electronic money, use behavior, public service.

Information technology has been rapidly growing during the last decade both in Indonesia and throughout the world. The rapid growth of technology has affected the financial technology sector in Indonesia. According to data from DailySocialid, the number of companies using financial technology increased to 196 companies in 2017 from 140 companies in 2016. The increase is due to the perceived ease, security, and practicality in using financial technology.

The 2016 data from Indonesia's Financial Technology Association (IFA) and Financial Services Authority of Indonesia (OJK) showed that the sectors of payment (42.2\%), lending $(17.78 \%)$ and aggregator (12.59\%) occupied the top three positions on the distribution of financial technology in Indonesia. The increased use of financial technology in the payment sector cannot be separated from the benefits received by consumers. Electronic money is one of the growing and most widely used financial technology products.

The 2016 data from Indonesia's Financial Technology Association (IFA) and Financial Services Authority of Indonesia (OJK) showed that the largest percentage in financial technology was the payment sector. However, the data obtained from the JakPat survey in 2017 showed that cash-based payment method was still the main choice of $77 \%$ consumers. The cash-based payment method is chosen because it is considered to be more measurable and accepted everywhere. Based on the description above, the questions raised are as follows:

- What are the characteristics of electronic money users in Jabodetabek?

- How do the relationship between characteristics users and behavioral intention to the use of electronic money?

- How do the relationship between characteristics users and behavioral intention to the use of electronic money?

Based on the problem statement, this study aims to:

1. Analyze the characteristics of electronic money users in Jabodetabek;

2. Analyze the relationship between characteristics users and behavioral intention to the use of electronic money;

3. Analyze the relationship between characteristics users and use behavior to the use of electronic money. 


\section{LITERATURE REVIEW}

Financial technology is a business sector with the second largest amount of investment in Indonesia by 2016 after E-Commerce (Tech in Asia Indonesia). Financial technology is intended to reduce the use of cash by the public and put forward the efficiency, practicality, and security. Due to its rapid growth, Bank Indonesia took steps to boost the growth of the financial technology industry and issued consumer protection regulation as well. One of the growing financial technology products is electronic money.

Behavioral intention is defined as the desire of consumers to behave according to certain ways in order to have, dispose of and use products or services (Mowen and Minor 2002). This understanding is in line with Venkatesh et al. 2003 which defines the intention to behave (behavioral intention) as a matter that refers to the intention of effective use by consumers of products or services in the future.

Behavior of Use (use behavior) is the level of use of technology observed and generated from intention to behave (Venkatesh et al. 2003). Furthermore, Davis (1989) explains that usage behavior is a tendency for behavior to continue using a technology. Correspondingly, Venkatesh et al. (2012) explains that use behavior is the behavior of use in using a technology.

According to Lovelock and Wirtz (2011), there are three stages in behavior of use, especially services. These stages include prepurchase, service encounter and postencounter. This stage helps to understand how consumers recognize their needs, look for alternative solutions, choose and experience being part of a service, and evaluate the results of experience, especially services. The description of the three stages is as follows:

The stage of pre-purchase is a situation where prospective consumers are aware of the need and continue to look for alternative information and evaluations to decide whether they are willing or not to buy certain services.

Service encounter stage is a situation where there is a real direct interaction between the customer and the service provider. During service delivery, many customers begin to evaluate the quality of services received and decide whether to meet their expectations.

Post-encounter stage At this stage, consumers will consider whether they will subsequently repurchase and become loyal customers or not. In this stage, customers will evaluate service performance and compare it with customer expectations.

Haywood's research (2017) states that use behavior is significantly affected by habit. Correspondingly, Sedana and Wijaya (2010) research shows that behavioral intention has a positive and significant correlation with use behavior.

\section{METHODS OF RESEARCH}

This study was conducted in Jakarta, Bogor, Depok, Tangerang, and Bekasi (Jabodetabek). Data collection took five months from April to August 2018. This study used a quantitative approach with survey method. The population in this study consisted of millennials aged 18-36 years (Howe and Strauss 2000) in Jabodetabek. The respondent sample criterion was the online transaction user and the sample size was 300 people. The sampling technique used was purposive sampling.

The data used were primary data obtained through the questionnaires. Additional data from previous studies in books and scientific writings on the internet were used as supports in completing the information. Data collection from respondents was using a structured questionnaire. It was conducted by distributing questionnaires online through google form to the target respondents extensively.

Descriptive analysis is a method used to describe the status of a group, people, an object, a concept, a condition, or an event in the present (Nazir 1998). According to Sumarwan (2011), this analysis is designed to collect information in an actual manner, describe a situation that occurs, and analyze the causes of a phenomenon, unable to control an event and asses what has already occurred. 
Validity and reliability tests were applied to 285 respondents and using SPSS 23 . This study used a significance level of $10 \%$ with $r$ table value at 0.113 . Thus all correlation coefficients generated by data processing exceeded $r$ table value of 0.113 or declared to be valid. A variable is reliable if it has Cronbach's alpha value $>0.6$ (Ghozali 2012). The reliability test results in this study were 0.96 that exceeded 0.6 .

\section{RESULTS AND DISCUSSION}

The results showed that $67.72 \%$ of information regarding the use of electronic money was obtained through the internet. The most frequently used electronic money product was Go-Pay (63.16\%) with the use intensity of fewer than ten times in one month $(56.84 \%)$. The most often purchased top-up balance was < 250,000 IDR (45.61\%) and the most commonly top-up method used was SMS/Internet Banking (64.21\%). The use of electronic money in Jabodetabek was dominated by transportation services at $37.33 \%$. The main reason for using electronic money was its practicality (47.02\%).

Cross tabulation analysis explained according to Santoso (2010) is a guideline in decision making in the chi square test in order to know the real differences of each variable tested in the study. In making decisions for this chi square test, it can be guided by two things, namely comparing the value of Asymp. Sig. with a critical limit of 0.1 or 10 percent. The output of processing different tests as in Table 1.

Table 1 - Results of Cross Tabulation of Demographic Characteristics, Behavioral Intention and Use Behavior (Crosstab)

\begin{tabular}{cccc|ccccc}
\hline Demographic & \multicolumn{3}{c|}{ Behavioral Intention } & \multicolumn{3}{c}{ Use Behavior } \\
\cline { 2 - 9 } Characteristics & BI1 & BI2 & BI3 & UB1 & UB2 & UB3 & UB4 & UB5 \\
\hline Gender & 0.41 & 0.97 & 0.46 & 0.22 & 0.04 & 0.44 & 0.35 & 0.45 \\
Age & 0.33 & 0.38 & 0.37 & 0.26 & 0.76 & 0.64 & 0.60 & 0.56 \\
Education & 0.09 & 0.04 & 0.47 & 0.45 & 0.12 & 0.56 & 0.21 & 0.46 \\
Occupation & 0.19 & 0.12 & 0.25 & 0.44 & 0.85 & 0.24 & 0.08 & 0.88 \\
Spending & 0.42 & 0.65 & 0.32 & 0.53 & 0.74 & 0.23 & 0.39 & 0.29 \\
Domicile & 0.93 & 0.95 & 0.45 & 0.89 & 0.81 & 0.51 & 0.89 & 0.60 \\
Transaction & 0.41 & 0.49 & 0.70 & 0.94 & 0.97 & 0.94 & 0.75 & 0.95 \\
\hline
\end{tabular}

Note: * Significant $<0.1$ and ${ }^{* *}$ Significant $<0.05$.

Based on the output results in Table 1 only 4 out of 56 parts were tested using cross tabulation. In parts that have a value above $>0.1$ or 10 percent are considered not to have a real difference or it can be interpreted that each part in the indicator is considered the same. In this case the management or electronic money application service provider company does not need to do different marketing activities in order to increase the intention and activity of using electronic money applications.

Table 2 - Cross Tabulation Percentage Comparison

\begin{tabular}{ccc}
\hline Uraian & Persentase $(\%)$ & Information \\
\hline Gender x UB2 & 44.08 & Female \\
Education x BI1 & 60.81 & Bachelor \\
Education x BI2 & 58.36 & Bachelor \\
Occupation x UB4 & 37.55 & Private Employees / Government Employees \\
\hline
\end{tabular}

In Table 1, it is known that the relationship that has a real difference after cross tabulation analysis is gender with indicators using electronic money applications to share types of transactions (UB2), education with indicators has the intention to use the future electronic money application (BI1), education with electronic money application indicators will be used in everyday life (BI2) and work with indicators deciding to become loyal users of electronic money applications (UB4). These findings need to be supported by additional information as in Table 2 to get more accurate results. 
Based on Table 2, it is known that management or electronic money application service provider companies need to focus on segmentation to increase intentions by looking at education and employment of consumers. In this case the electronic money application service provider companies need to target consumers who have undergraduate education. In addition, companies also need to target consumers of gender and occupational backgrounds. The results of the comparison of cross tabulation percentage in this study indicate that consumers with female gender are considered to have better prospects for using electronic money applications, besides Private Employees / Government Employees also have great potential as a target of loyal consumers to use electronic money applications.

The main objective of this study was to analyze the characteristics of electronic money users in Jabodetabek, analyze the relationship between demographic characteristics of users of electronic money applications to use intentions and behavior towards the use of electronic money applications. The importance of this research is that we can find out that the use of electronic money in Indonesia, especially Jabodetabek, is very large than cash. The most frequently used electronic money product was Go-Pay $(63.16 \%)$ with the use intensity of fewer than ten times in one week (56.84\%). The most often purchased top-up balance was < 250,000 IDR (45.61\%) and the most commonly top-up method used was SMS/Internet Banking (64.21\%). The use of electronic money in Jabodetabek was dominated by transportation services at $37.33 \%$. The main reason for using electronic money was its practicality (47.02\%).

Companies need to better identify and set user targets so that the company's marketing activities are right on the specified targets. This is so that the company can maximize profits with the growth of new customers and retain existing users. The company can focus its target on the female community because of its intensity in making larger transactions. In addition, the community with an education level of undergraduate and community members who work as private employees / BUMNs is also the next target. This is because the majority of private employees / BUMN are graduates who are always looking for easy and practical things in increasing productivity.

Companies need to maintain the ease of process when using electronic money applications, one of which is by making features that are user friendly so that consumers feel comfortable in their use. In addition, the company needs to maintain several features that are advantages of electronic money applications such as the speed of application of electronic money in transactions, convenience in using electronic money applications for new users and the suitability of nominal transactions that must be paid by consumers after the products or services ordered. also need to review promotional policies through various forms such as cashback, discounts and rewards for loyal users so as not to move to competitors. On the other hand, companies need to pay attention to the protection of user information and minimize loopholes in the electronic money application application system so as not to harm the user.

\section{CONCLUSION}

The results showed that $67.72 \%$ of information about the use of electronic money was obtained through the internet. The most frequently used electronic money product was GoPay $(63.16 \%)$ with the use intensity of fewer than ten times in one month (56.84\%). The most often purchased top-up balance was $<250,000$ IDR $(45.61 \%)$ and the most commonly top-up method used was SMS/Internet Banking (64.21\%). The use of electronic money in Jabodetabek was dominated by transportation services at $37.33 \%$. The main reason for using electronic money was its practicality (47.02\%).

This research has limitations in the form of focusing on the financial and $Y$ technology payment sector in Jabodetabek. In addition, this research also emphasizes from the consumer's perspective so that it does not look at it from the point of view of the business actor. It is suggested to conduct a further study with other sectoral approaches but payment on financial technology. Moreover, it studies a broader object and not only focus on one 
generation. The study objects are not only electronic money users but those who have not used electronic money as well.

For consumers who will use the electronic money application, they need to pay attention to the rules made by the company, especially for activities related to sales promos. Consumers who have used the electronic money application when making transactions need to pay attention to the last balance in the electronic money application application to minimize the mismatch that will occur. Consumers who have become loyal users can invite the surrounding environment especially to use electronic money applications because of the various advantages and conveniences offered.

\section{REFERENCES}

1. Dailysocialid. 2017. Fintech Report. . [internet] [Diacu 05 Februari 2018]. Tersedia dari: http://www.dailysocialid.id.

2. Davis FD. 1989. Perceived usefulness, perceived ease of use and user acceptance of information technology. Journal MIS Quarterly. 2(3): 34-42.

3. Ghozali I. 2012. Aplikasi Analisis Multivariate dengan Program IBM SPSS. Yogyakarta (ID): Universitas Diponegoro

4. Haywood D. 2017. The Relationship between Nonprofit Organizations and Cloud Adoption Concerns. Walden University

5. Howe N, Strauss W. 2000. Millennials rising: The next great generation. Vintage

6. [IFA] Indonesia's Fintech Association and [OJK] Otoritas Jasa Keuangan. 2016. Financial Technology di Indonesia.

7. Jakpat. 2017. Are you cashless society?. [internet] [Diacu 11 Februari 2018]. Tersedia dari: http://Jakpat.net.

8. Jakpat. 2017. Online ride booking apps. [internet] [Diacu 11 Februari 2018]. Tersedia dari: http://Jakpat.net.

9. Lovelock C, Wirtz J, 2011. Pemasaran Jasa Perspektif edisi 7. Jakarta (ID): Erlangga

10. Mowen C, Minor JM. 2002. Perilaku Konsumen. Jakarta (ID): Erlangga

11. Nazir M. 1998. Metode Penelitian. Jakarta (ID): Ghalia Indonesia.

12. Santoso S. 2010. Statistik parametrik. Jakarta (ID): Elex Media Komputindo.

13. Sedana IGN and Wijaya SW. 2010. UTAUT model for understanding learning management system. Universitas Sanata Dharma. Internet Working Indonesia Journal. 2(2):22-34

14. Sumarwan U. 2011. Perilaku konsumen: Teori and penerapannya dalam pemasaran. Bogor (ID): Ghalia Indonesia

15. Techinasia. 2016. Kilas balik perkembangan layanan transportasi online di tahun 2016. [internet]. [diakses pada: 2018 Februari 05]. Tersedia pada: www.techinasia.com.

16. Venkatesh V, Morris G, Davis G, Davis, F. 2003. User acceptance of information technology: Toward a unified view. Mis Quarterly. 27(3): 425-478.

17. Venkatesh V, Thong JYL, Xu X. 2012. Consumer acceptance and use of information technology: Extending the unified theory of acceptance and use of technology. Mis Quarterly. 36 (1): 157-178.

18. Waluyo M. 2011. Panduan and Aplikasi Structural Equation Modelling (Untuk Aplikasi Model dalam Penelitian Teknik Industri, Psikologi, Sosial and Manajemen). Jakarta (ID): PT. Indeks 